\title{
Mutation of a Highly Conserved Residue of $\beta$ I Spectrin Associated with Fatal and Near-fatal Neonatal Hemolytic Anemia
}

\author{
Patrick G. Gallagher, ${ }^{\star}$ Mary Jane Petruzzi, ${ }^{\star \star}$ Scott A. Weed, ${ }^{\ddagger}$ Zhushan Zhang, ${ }^{\S}$ Sally L. Marchesi, ${ }^{\S}$ Narla Mohandas, ${ }^{\ddagger \ddagger}$ \\ Jon S. Morrow, ${ }^{\S}$ and Bernard G. Forget ${ }^{\mathbb{T}}$ \\ $*$ Department of Pediatrics, ${ }^{\ddagger}$ Department of Cell Biology, ${ }^{\S}$ Department of Pathology, ${ }^{\pi}$ Department of Internal Medicine, and $\|^{\|}$epartment \\ of Genetics, Yale University School of Medicine, New Haven, Connecticut 06520; **Hematology/Oncology Division, The Children's \\ Hospital of Buffalo, Buffalo, New York 14222; and ${ }^{\ddagger}$ Life Sciences Division, Lawrence Berkeley National Laboratory, University of \\ California, Berkeley, California 94720
}

\begin{abstract}
We studied an infant with severe nonimmune hemolytic anemia and hydrops fetalis at birth. His neonatal course was marked by ongoing hemolysis of undetermined etiology requiring repeated erythrocyte transfusions. He has remained transfusion-dependent for more than $2 \mathrm{yr}$. A previous sibling born with hemolytic anemia and hydrops fetalis died on the second day of life. Peripheral blood smears from the parents revealed rare elliptocytes. Examination of their erythrocyte membranes revealed abnormal mechanical stability as well as structural and functional abnormalities in spectrin. Genetic studies revealed that the proband and his deceased sister were homozygous for a mutation of $\beta I \Sigma 1$ spectrin, L2025R, in a region of spectrin that is critical for normal function. The importance of leucine in this position of the proposed triple helical model of spectrin repeats is highlighted by its evolutionary conservation in all $\beta$ spectrins from Drosophila to humans. Molecular modeling demonstrated the disruption of hydrophobic interactions in the interior of the triple helix critical for spectrin function caused by the replacement of the hydrophobic, uncharged leucine by a hydrophilic, positively charged arginine. This mutation must also be expressed in the $\beta I \Sigma 2$ spectrin found in muscle, yet pathologic and immunohistochemical examination of skeletal muscle from the deceased sibling was unremarkable. (J. Clin. Invest. 1997. 99:267-277.) Key words: membrane skeleton • mutation • molecular modeling • skeletal muscle $\cdot$ spectrin
\end{abstract}

\section{Introduction}

Intrinsic defects of the erythrocyte constitute an important group of inherited disorders that cause hemolytic anemia in the neonate. Uncommonly, these disorders are manifest in

Portions of this work have been published in abstract form (1994. Blood. 84[Suppl.1]:112a).

Address correspondence to B.G. Forget, M.D., Hematology Section, Department of Internal Medicine, Yale University School of Medicine, 333 Cedar Street, P.O. Box 208021, New Haven, CT 065208021. Phone: 203-785-4144; FAX: 203-785-7232; E-mail: Forget BG@MASPO1.MAS.Yale.edu

Received for publication 16 July 1996 and accepted in revised form 15 November 1996.

J. Clin. Invest.

(C) The American Society for Clinical Investigation, Inc.

0021-9738/97/01/267/11 \$2.00

Volume 99, Number 2, January 1997, 267-277 utero with severe anemia and hydrops fetalis (1). Diseases that have been associated with hemolytic anemia and nonimmune hydrops fetalis include the $\alpha$-thalassemia syndromes, deficiencies of erythrocyte enzymes, and very rarely, abnormalities of the erythrocyte membrane skeleton (1).

Defects of the erythrocyte membrane have been well characterized in cases of severe neonatal hemolytic anemia due to recessive hereditary spherocytosis and homozygous hereditary elliptocytosis/pyropoikilocytosis (HE/HPP) $)^{1}$ (2-9). Two well documented kindreds with fatal or near-fatal anemia and hydrops fetalis associated with erythrocyte membrane defects have been described $(10,11)$. In both cases, defects were identified in spectrin, the principal structural protein of the erythrocyte membrane. Whitfield et al. (11) reported virtually absent synthesis of $\alpha \mathrm{I}$ spectrin $^{2}$ in a fetus with nonimmune hemolytic anemia, abnormal osmotic fragility, and hydrops fetalis. In utero red blood cell (RBC) transfusions were given; after birth, the child remained transfusion-dependent despite splenectomy at 14 mo of age. The patient's mother suffered from typical hereditary spherocytosis. The father had a normal hemoglobin, reticulocyte count and peripheral blood smear, but had a mildly abnormal osmotic fragility. The precise genetic defect(s) in this family has yet to be characterized. In a second kindred, four third trimester fetal losses occurred associated with hemolytic anemia and hydrops fetalis (10). Studies of erythrocytes and erythrocyte membranes from the parents showed abnormal membrane stability as well as structural and functional abnormalities in $\beta I \Sigma 1$ spectrin. A point mutation in the $\beta I$-spectrin gene, S2019P (spectrin Providence), was identified in the heterozygous state in the parents and in the homozygous state in the three deceased infants studied.

Spectrin, the principal structural component of the erythrocyte membrane skeleton, is composed of two structurally similar but nonidentical proteins, $\alpha I$ and $\beta I$ spectrin. $\alpha I$ and $\beta I$ spectrin are composed primarily of homologous 106-amino acid repeats that fold into three antiparallel $\alpha$-helices connected by short nonhelical segments $(15,16)$. $\alpha$ I and $\beta I$ spectrin combine to form heterodimers, which in turn self-associate to form tetramers and higher order oligomers. These tetramers and oligomers form a lattice-like structure that is critical for

1. Abbreviations used in this paper: DI, deformability index; HE, hereditary elliptocytosis; HPP, hereditary pyropoikilocytosis; IEF, isoelectric focusing; RBC, red blood cell.

2. The nomenclature of spectrin isoforms used in this manuscript is described in references 12-14. Spectrins are described by their subunit type ( $\alpha$ or $\beta$ ), their gene of origin in order of discovery (e.g., I, II, etc.), and alternate transcripts in order of discovery (e.g., $\Sigma 1, \Sigma 2$, etc.). 
Table I. Laboratory Studies of the Proband, II-4

\begin{tabular}{|c|c|}
\hline $\mathrm{Hb}(\mathrm{g} / \mathrm{dl})$ & $7-10^{*}$ \\
\hline $\operatorname{MCV}(f l)$ & 74-83* \\
\hline Reticulocyte count (\%) & $0-19 *$ \\
\hline Erythrocyte morphology & $\begin{array}{l}\text { Nucleated RBCs, } \\
\text { microspherocytes }\end{array}$ \\
\hline Bone marrow (age $15 \mathrm{mo}$ ) & $\begin{array}{l}\text { Marked erythroid hyperplasia, } \\
\text { increased iron stores }\end{array}$ \\
\hline Total bilirubin (mg/dl) & $2.4-3.2$ \\
\hline LDH (U/liter) & $500-700$ \\
\hline Haptoglobin (mg/dl) & $<4$ \\
\hline Osmotic fragility & Normal* \\
\hline Hb electrophoresis (cord blood) & A $14 \%$, F $83 \%$, Barts $2 \%$ \\
\hline Unstable hemoglobin & Negative \\
\hline $\begin{array}{l}\text { DEB-treated chromosomal } \\
\text { breakage }\end{array}$ & Normal \\
\hline Bone marrow parvovirus PCR & Negative \\
\hline RBC enzymes ${ }^{\ddagger}$ & Normal or increased* \\
\hline
\end{tabular}

*During chronic transfusion therapy, 2-3 wk after transfusion. ${ }^{\ddagger} \mathrm{RBC}$ enzymes assayed included glucose-6-phosphate dehydrogenase, hexokinase, glucose phosphate dehydrogenase, triose phosphate isomerase, and phosphofructokinase.

erythrocyte membrane stability as well as erythrocyte shape and deformability. Qualitative and quantitative disorders of both $\alpha \mathrm{I}$ and $\beta \mathrm{I}$ spectrin have been associated with abnormalities of RBC shape including hereditary spherocytosis, HE, and HPP (17-19).

This report describes a Laotian infant with severe Coombsnegative hemolytic anemia ( $\mathrm{Hb} 2.7 \mathrm{~g} / \mathrm{dl})$ and gross hydrops fetalis at birth. His neonatal course was marked by ongoing hemolytic anemia requiring erythrocyte transfusions. He has remained transfusion dependent for $2 \mathrm{yr}$; his blood smears reveal only normal erythrocytes which represent transfused cells and a few microspherocytes and nucleated erythrocytes. Family history is remarkable for a previous sibling born with hemolytic anemia and hydrops fetalis; she died on the second day of life. Her autopsy revealed marked extramedullary erythropoiesis and changes consistent with widespread tissue hypoxia. Examination of erythrocytes from the parents revealed very rare elliptocytes and studies of their erythrocyte
Table II. Laboratory Studies of the Proband's Parents

\begin{tabular}{lll}
\hline & \multicolumn{1}{c}{ Mother I-1 } & \multicolumn{1}{c}{ Father I-2 } \\
\hline $\mathrm{Hb}(\mathrm{g} / \mathrm{dl})$ & 13.3 & 14.9 \\
$\mathrm{MCV}(\mathrm{fl})$ & 78 & 76 \\
Reticulocyte count $(\%)$ & 1.6 & 1.34 \\
RBC morphology & Rare elliptocytes & Rare elliptocytes \\
Osmotic fragility & Normal & Normal \\
Hb electrophoresis & A + A2 & A + A2 \\
& & \\
\hline
\end{tabular}

membranes revealed abnormal mechanical stability as well as structural and functional abnormalities in spectrin.

Genetic studies revealed that the proband and his deceased sister were homozygous for a point mutation of $\beta I$ spectrin, L2025R, in a region of $\beta$ spectrin that is critical for normal spectrin function $(15,20-22)$. The parents were heterozygous for this mutation. The importance of leucine in this position of the proposed model of triple helical spectrin repeats is highlighted by its evolutionary conservation in all $\beta$ spectrins from Drosophila to humans. Dynamic molecular modeling of the self-association domain suggests that hydrophobic interactions in the interior of the triple helix critical for spectrin function are disrupted by the replacement of the hydrophobic, uncharged leucine by a hydrophilic, positively charged arginine. Although an alternative transcript of $\beta$ I spectrin, $\beta I \Sigma 2$, which is expressed in muscle and brain $(12,23)$, must contain the mutation, pathologic and immunohistochemical examination of skeletal muscle from the deceased sibling was unremarkable. We have named this variant spectrin Buffalo.

\section{Methods}

\section{Patients}

The proband is the product of an apparently nonconsanguineous mating of a Laotian couple. His perinatal course was complicated by hydrops fetalis, diagnosed at $31 \mathrm{wk}$ of gestation. Cordocentesis at this time detected severe anemia $(\mathrm{Hb} 2.7 \mathrm{~g} / \mathrm{dl})$. In utero red cell transfusion was unsuccessful due to fetal distress, and a Caesarean section was performed. Birth weight was 1,600 g, Apgars were $0^{1}, 0^{5}, 3^{10}, 3^{15}$. Laboratory studies on cord blood revealed the following: $\mathrm{Hb} 2.7 \mathrm{~g} / \mathrm{dl}$; negative direct and indirect antiglobulin tests; hemoglobin electrophoresis: A $14 \%$, F $83 \%$, and Barts $2 \%$. A double volume exchange
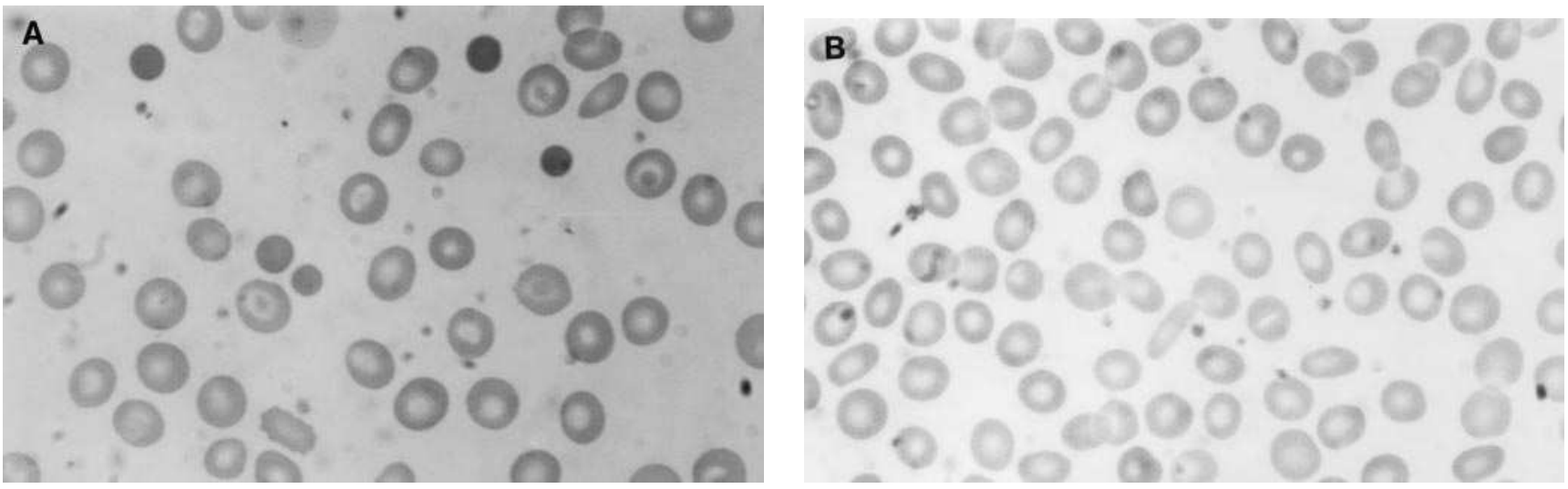

Figure 1. Peripheral blood smears. Microspherocytes are seen in peripheral blood smears from the proband $(A)$ and microcytosis and rare elliptocytes are noted in peripheral blood smears from the father $(B)$. 


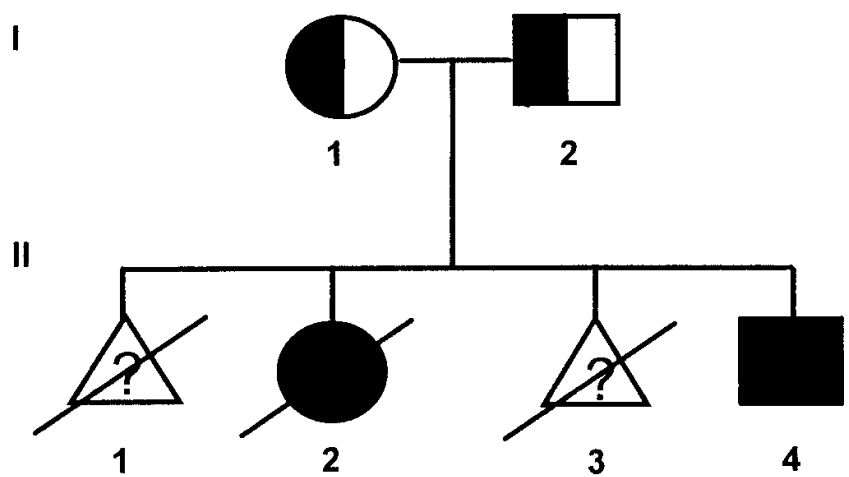

Figure 2. Pedigree of the spectrin Buffalo family. The diagonal lines through the symbols indicate stillborn or perinatally deceased infants. Triangles indicate first trimester spontaneous abortions.

transfusion was performed. Several RBC transfusions were given due to persistent hemolytic anemia. Phototherapy was required to treat protracted hyperbilirubinemia. Mechanical ventilation was required for $22 \mathrm{~d}$.

Now $2 \mathrm{yr}$ of age, the patient has required chronic RBC transfusions every 3-4 wk due to persistent anemia. His peripheral blood smear shows microspherocytes and nucleated RBCs, with predominantly normal RBC morphology representing transfused cells (Fig. 1A). His hematocrit did not increase after a trial of steroids. A trial of recombinant human erythropoietin led to increased evidence of hemolysis without an increase in the $\mathrm{Hb}$ level. Numerous diagnostic studies were performed in an attempt to detect the cause of the ongoing hemolytic anemia (Table I). Hematologic studies performed on the parents (Table II) revealed that both parents had very mild elliptocytosis (Fig. $1 \mathrm{~B}$ ). Currently, the patient has no clinical symptoms of muscle dysfunction.

The maternal obstetrical history is remarkable for three previous pregnancies (Fig. 2). The second pregnancy was also complicated by fetal hydrops and hemolytic anemia (cord blood $\mathrm{Hb} 3.8 \mathrm{~g} / \mathrm{dl}$ ). This $37-w k$ gestation infant died on the second day of life. Autopsy revealed evidence of diffuse tissue hypoxia and marked extramedullary erythropoiesis (Fig. 3). Two other pregnancies resulted in spontaneous fetal losses in the first trimester. Further studies to determine the etiology of the hydrops fetalis and hemolytic anemia experienced by the two infants of this kindred are detailed below.

\section{Mechanical stability of erythrocyte membranes}

Resealed membranes were prepared according to a procedure adapted from Johnson (24). For mechanical stability measurements, $150 \mu \mathrm{l}$ of membrane suspension was mixed with $3.5 \mathrm{ml}$ of a dextran solution (290 mOsmol, pH 7.4 and viscosity 95 centipoise) and subjected continuously to $750 \mathrm{dyn} / \mathrm{cm}^{2}$ in the ektacytometer (25). Under this stress, the membranes progressively fragment, generating undeformable spheres. This process is detected as a time-dependent decrease in the deformability index (DI). The rate of decline of DI is a measure of membrane mechanical stability.

\section{Studies of erythrocyte membrane proteins}

Erythrocyte membrane preparation and quantitation. Erythrocyte membranes were prepared from peripheral blood as described previously $(26,27)$. Membrane proteins were separated by SDS-PAGE in 3.5$17 \%$ gradient polyacrylamide gels and stained with Coomassie blue. Spectrin/band 3 ratios were obtained by scanning the stained gels using the Personal Densitometer Laser Scanner (Molecular Dynamics, Sunnyvale, CA) and then calculating the staining intensity of individual protein bands using Imagequant software (Molecular Dynamics).

Limited tryptic digestion of spectrin. Spectrin was extracted by incubating ghosts overnight at $4^{\circ} \mathrm{C}$ in low ionic strength buffer (28). Limited tryptic digests of spectrin extracts were prepared as described (27) and separated by two-dimensional fractionation using SDS-PAGE and isoelectric focusing (IEF) as modified by Speicher et al. (29).

Study of spectrin self-association. The amount of spectrin dimers compared with spectrin tetramers in spectrin extracted from membrane ghosts under conditions of low ionic strength at $4^{\circ} \mathrm{C}$ was determined by nondenaturing gel electrophoresis as described (30).

\section{Molecular genetic analyses}

Oligonucleotide synthesis, preparation, and amplification of genomic $D N A$. Synthetic oligonucleotides were synthesized using an automated synthesizer (Applied Biosystems, Foster City, CA) and purified by gel electrophoresis or oligonucleotide purification column chromatography (Applied Biosystems). The sequences of the primers used in PCR and sequencing are listed in Table III. Genomic DNA was isolated from leukocytes and amplified by PCR as described by Sahr et al. (31). For infant II-2, DNA was extracted from 5- $\mu \mathrm{m}$-thick sections taken from paraffin blocks of autopsy tissue (liver and spleen) as described (32).

Subcloning and nucleotide sequencing of PCR-amplified genomic $D N A$. Subcloning and nucleotide sequencing of PCR-amplified genomic DNA were completed as described (7).
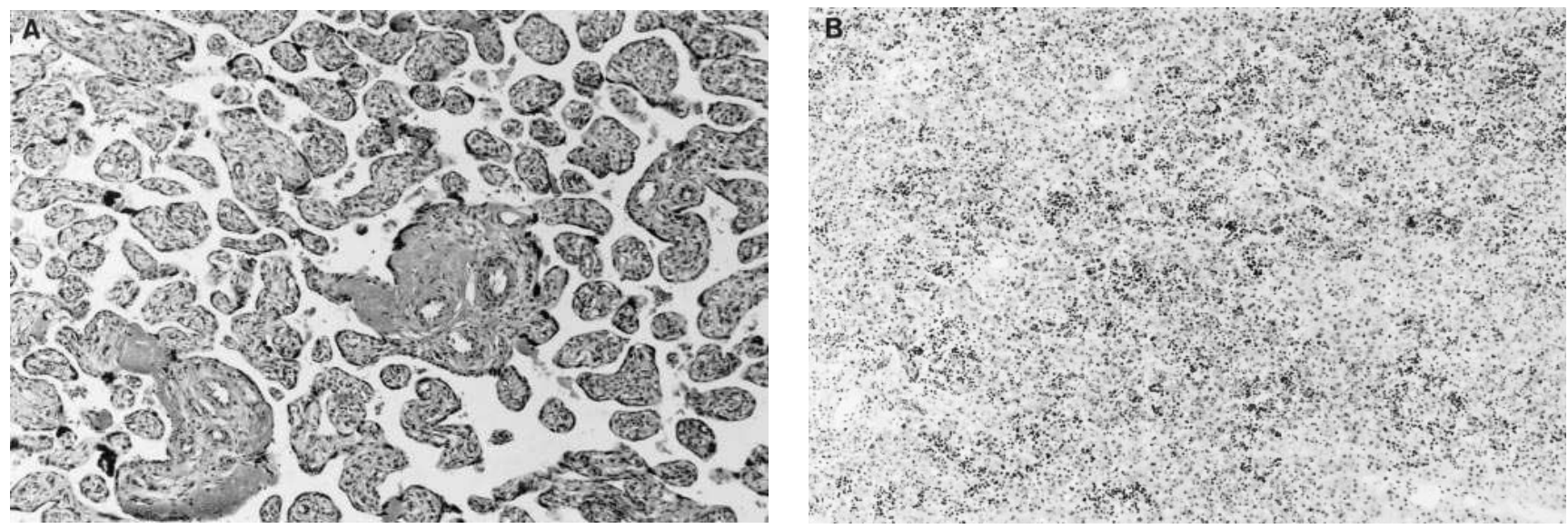

Figure 3. Histopathology of tissues from deceased infant II-2. (A) Villous edema and nucleated RBCs in villous vessels are seen in a placental section (hematoxylin and eosin, $\times 10$ ). (B) Extensive extramedullary erythropoiesis, as evidenced by the multiple nucleated RBCs, is seen in a section of liver (hematoxylin and eosin, $\times 20$ ). 
Table III. Oligonucleotide Primers

\begin{tabular}{|c|c|}
\hline Primer & Gene \\
\hline & $\alpha \mathrm{I}$-spectrin \\
\hline A & $\begin{array}{l}\text { 5'-CGTGAATTCTGAGAACTAGCAATTAACAG-3' } \\
\text { (sense, intron 1) }\end{array}$ \\
\hline \multirow[t]{2}{*}{ B } & $\begin{array}{l}\text { 5'-CGTGGATCCCCATTAACATTAACATAAAG-3' } \\
\quad(\text { antisense, intron 2) }\end{array}$ \\
\hline & $\beta I$-spectrin \\
\hline $\mathrm{C}$ & $\begin{array}{l}\text { 5'-GCGAATTCAGGAGTGAACGATTGGGTGCT-3' } \\
\text { (sense, intron 29) }\end{array}$ \\
\hline $\mathrm{D}$ & $\begin{array}{l}\text { 5'-CGAAGCTTGGTCCCAATGTCAGGT-3' } \\
\text { (antisense, intron 32) }\end{array}$ \\
\hline $\mathrm{E}$ & $\begin{array}{l}\text { 5'-GCGAATTCGCAGGAGGCTCTGGCCT-3' } \\
\text { (sense, intron 32) }\end{array}$ \\
\hline $\mathrm{F}$ & $\begin{array}{l}\text { 5'-CGAAGCTTGCGCAGCTCATCTCGCCT-3' } \\
\text { (antisense, } 3^{\prime} \text { untranslated) }\end{array}$ \\
\hline $\mathrm{G}$ & $\begin{array}{l}5^{\prime} \text {-TCTCAAAAGCCTCATGCCTC-3' } \\
\text { (sense, } \beta \text {-spectrin cDNA) }\end{array}$ \\
\hline $\mathrm{H}$ & $\begin{array}{l}\text { 5'-CTGTTCCCTGCTCACCGTGGTG-3' } \\
\text { (antisense, intron 31) }\end{array}$ \\
\hline
\end{tabular}

\section{Dynamic protein modeling}

The coordinates of the crystal structure of the 14th repeat unit of Drosophila $\alpha$ spectrin were used as the starting point for all modeling studies (16). The sequence of the 17th unit of $\beta$ I spectrin, which represents about two-thirds of a normal repeat unit, was concatenated with the residues involved with self-association near the $\mathrm{NH}_{2}$ terminus of $\alpha \mathrm{I}$ spectrin, which comprise about one-third of the normal repeat unit. The combined sequence, representing the complete triple helical "repeat unit" that accounts for self-association (20), was aligned with the 14th repeat unit of Drosophila $\alpha$ spectrin using the program Bestfit ${ }^{\mathrm{TM}}$ (33). The corresponding residues of human $\alpha \mathrm{I}$ and $\beta I$ spectrin were then graphically incorporated into the published crystallographic coordinates of Drosophila spectrin, using the program Insight ${ }^{\mathrm{TM}}$ (1993. Biosym Technologies, San Diego, CA), creating a starting structure for the dynamic modeling computations. These computations, based on simulated annealing from 1,000 to $100^{\circ} \mathrm{K}$ and energy minimization algorithms (34), include placing the starting structure in a $6-\AA$ water shell that contains $\sim 1,100$ water molecules. The application of this approach and its fidelity has been described (Stabach, P.R., C.D. Cianci, S.B. Glantz, Z. Zhang, and J.S. Morrow, manuscript submitted for publication; and Zhang, Z., S.A. Weed, and J.S. Morrow, manuscript in preparation). Minimized structures were displayed using Insight ${ }^{\mathrm{TM}}$ molecular display software. All computations were carried out using an Indigo ${ }^{\text {Two }}$ Extreme $^{\mathrm{TM}}$ workstation (Silicon Graphics, Inc., Mountain View, CA).

\section{Examination of skeletal muscle}

Pathologic examination. Formalin-fixed, paraffin-embedded, skeletal muscle (psoas) was obtained from autopsy material of individual II-2 who is homozygous for the spectrin Buffalo mutation. Control skeletal muscle sections were obtained from an age-matched control without clinical or anatomic evidence of a neuromuscular defect. Hematoxylin and eosin stains were performed using standard techniques.

Immunohistochemistry. Immunoperoxidase staining was performed as described with one modification $(35,36)$. After rehydration of the dehydrated tissue sections in water for $5 \mathrm{~min}$, antigenicity was enhanced by heat-treating the sections in a pressure cooker with boiling $10 \mathrm{mM}$ sodium citrate, $\mathrm{pH} 6.0$, for $5 \mathrm{~min}$ (37). A polyclonal $\beta$-spectrin antibody raised to a recombinant protein specific for domain III of $\beta I \Sigma 2$ spectrin was used for immunostaining $(35,38)$. Sec- tions were examined and photographed using an Olympus Vanox microscope equipped with a Roche image analysis systems digital camera.

\section{Results}

\section{Mechanical stability of erythrocyte membranes}

The mechanical stability and rigidity of erythrocyte membranes were examined using an ektacytometer. Ektacytometric measurements of mechanical stability of membranes derived from erythrocytes of both parents are shown in Fig. 4. The rate of decline of the DI (a measure of mechanical stability) of erythrocyte membranes from both parents was much faster than that of normal membranes, implying a marked decreased in mechanical stability. As shown in Fig. 4, the mechanical stability of these membranes was intermediate between membranes of erythrocytes from an individual heterozygous for an $\alpha \mathrm{I}$-spectrin gene mutation causing nonhemolytic $\mathrm{HE}$ and those from an individual doubly heterozygous for two different $\alpha I$-spectrin gene mutations causing HPP (39). Membranes from the proband's parents were also abnormally rigid: compared with normal membranes, the dynamic rigidity of their RBC membranes was increased two- to threefold (data not shown).

\section{Studies of erythrocyte membrane proteins}

Qualitative and quantitative analyses of erythrocyte membrane proteins. One-dimensional SDS-PAGE analyses of erythrocyte membrane proteins from the mother, father, and infant II-4 were qualitatively normal (data not shown). Quantitative analysis of spectrin content, measured by the ratio of spectrin/ band 3, was normal in the mother (1.04), the father (0.98), and proband II-4 (1.14), compared with that of a normal control subject (1.00).

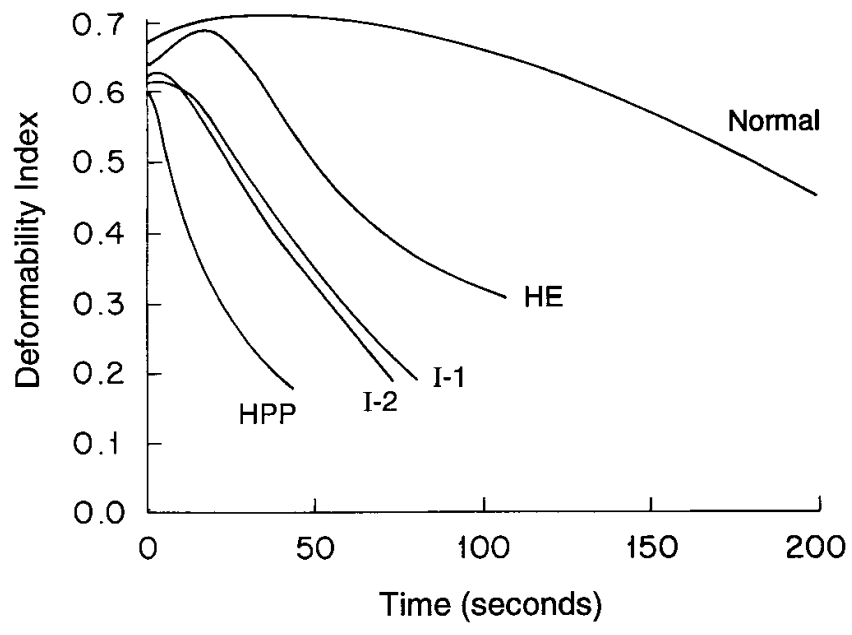

Figure 4. Ektacytometric analysis of mechanical stability of erythrocyte membranes. Resealed ghosts prepared from a normal control subject and the parents of the spectrin Buffalo kindred (I-1 and I-2) erythrocytes were subjected to shear stress in an ektacytometer and the decline of the DI was measured as a function of time. The rate of DI decline is a measure of membrane mechanical stability. Red cell membranes from both parents fragmented more rapidly than normal membranes. The fragmentation curves of these membranes were intermediate between those previously reported (39) for nonhemolytic heterozygous HE and for HPP associated with mutations of the $\alpha$-spectrin gene. 


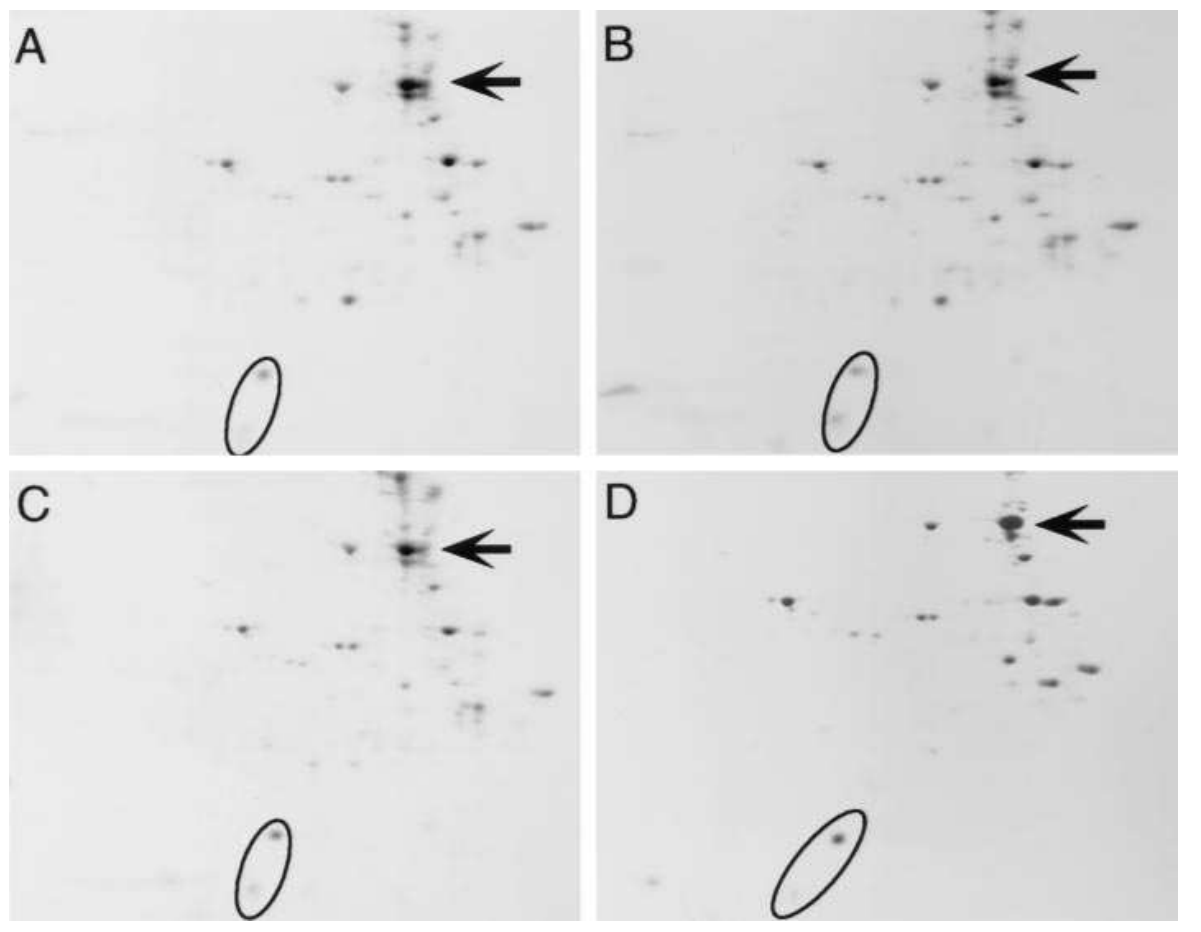

Figure 5. Limited tryptic digestion of spectrin. Red cell spectrin from members of the spectrin Buffalo kindred was partially digested with trypsin and fractionated by two-dimensional gel electrophoresis with IEF (SDS/PAGE with IEF). Spectrin digests from the parents $(A$ and $B$ ) show the normal $80-\mathrm{kD}$ T $\alpha-1$ spectrin peptide (arrows) and markedly increased amounts of the 74-kD T $\alpha-1$ spectrin peptide just below the $80-\mathrm{kD}$ T $\alpha-1$ peptide compared with normal. A small amount of the $74-\mathrm{kD}$ T $\alpha-1$ spectrin peptide is seen in the tryptic map of the proband $(C), 2.5 \mathrm{wk}$ after RBC transfusion. Also note the T $\beta$-I peptides (circled) and the absence of left-shifted (more basic) peptide that would be expected if the mutant T $\beta$-I domain was stably present. $A$, mother I- $1 ; B$, father I-2; $C$, proband II-4; $D$, normal control.

Limited tryptic digestion of spectrin. After limited digestion with trypsin followed by two-dimensional gel electrophoresis, normal spectrin can be resolved into five $\alpha$ and four $\beta$ major proteolytically resistant domains $(16,29,40)$. The $\mathrm{NH}_{2}$ terminus of $\alpha$ spectrin, the $80-\mathrm{kD}$ T $\alpha-\mathrm{I}$ domain, ${ }^{3}$ interacts with the sequences of the 17 th repeat of $\beta I$ spectrin to form the binding site for spectrin self-association $(20,41)$. Limited tryptic digestion of spectrin followed by two-dimensional fractionation using SDS-PAGE and IEF (Fig. 5, $A$ and $B$ ) revealed increased amounts of a 74-kD T $\alpha$-I spectrin peptide in both parents. A very small amount of the $74-\mathrm{kD}$ T $\alpha$-I peptide was observed in spectrin digests from the proband II-4 (Fig. 5 C), 2.5 wk after an erythrocyte transfusion. This $74-\mathrm{kD}$ peptide is derived from the normal $\mathrm{NH}_{2}$-terminal $80-\mathrm{kD}$ peptide of T $\alpha$-I spectrin and is frequently seen in increased amounts in certain cases of $\mathrm{HE}$ and HPP, usually associated with structural defects of the $\mathrm{NH}_{2}$ terminus of $\alpha \mathrm{I}$ spectrin or, more rarely, with structural defects within the self-association domain of $\beta$ I spectrin (17).

Evidence for changes in the digestion of the T $\beta$-I peptide, which is derived from the 17 th repeat and the $\mathrm{COOH}$ terminus of $\beta$ I spectrin, was also sought (42). Based on the nature of the spectrin Buffalo mutation, leucine to arginine (see below), one would expect to identify a basic shift of the T $\beta$-I peptide (Fig. 5). In both parents and the proband, only the wild-type T $\beta$-I peptide was observed, with no additional more basic peptides consistently found in this region. The absence of the mutant T $\beta$-I peptide in digests of spectrin extracted from the proband or his parents suggests that the spectrin Buffalo mutation renders this domain unstable after limited trypsin diges-

3. A uniform nomenclature for spectrins and their isoforms has been adopted (see above). It has been proposed that the tryptic peptides of spectrin, previously called $\alpha \mathrm{I}, \alpha \mathrm{II}$, etc., be denoted with the prefix T-, designating them as tryptic fragments, e.g., T $\alpha$-I. This convention will avoid future confusion with the uniform nomenclature. tion, a result predicted by the dynamic molecular modeling studies described below.

Spectrin self-association assays. Studies of spectrin's ability to self-associate were performed using spectrin extracted

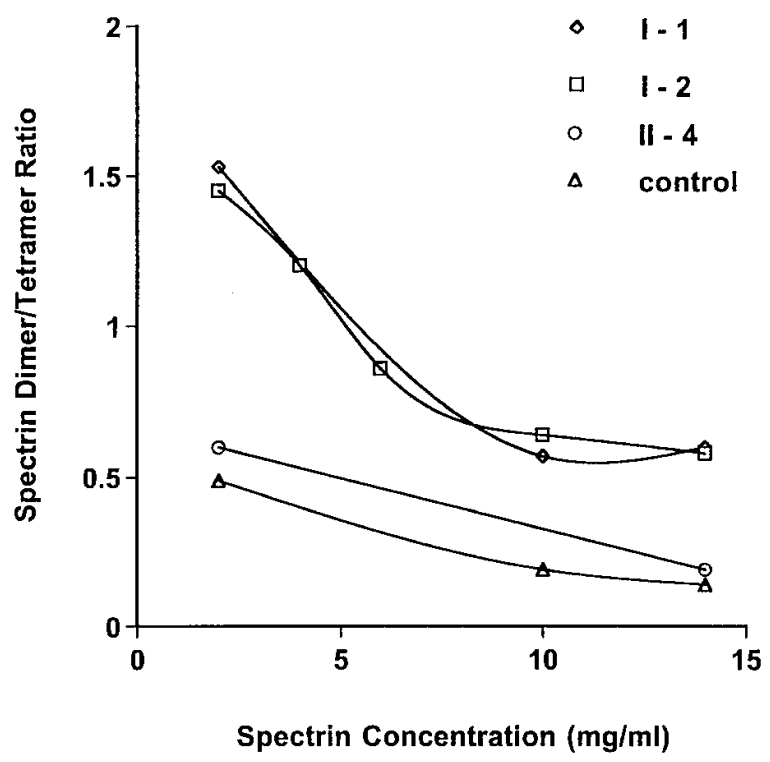

Figure 6. Spectrin self-association assays. Studies of spectrin selfassociation were performed using spectrin extracted from erythrocyte membrane ghosts at low ionic strength at $4^{\circ} \mathrm{C}$ and then equilibrated at various concentrations. The increased amounts of spectrin dimers compared with tetramers at higher concentrations of the parent's spectrin indicate a moderate degree of impairment of spectrin selfassociation. Spectrin extracted from the erythrocytes of the proband II-4 immediately before transfusion had a similar self-association profile to that of normal control spectrin and probably consists mostly of spectrin extracted from transfused erythrocytes. 
from erythrocyte ghosts under conditions of low ionic strength at $4^{\circ} \mathrm{C}$ and equilibrated at various concentrations. The impaired formation of tetramers as a function of spectrin concentration is most apparent in the parents (Fig. 6) and indicates a moderate degree of impairment of spectrin self-association in these individuals.

The effect of this mutation on the relative association constant $(K a)$ for tetramer formation, compared with that of the normal protein, can be approximated in these experiments by comparing the ratio of dimer $(D)$ to tetramer $(T)$ for both mutant $(m)$ and wild-type $(w t)$ spectrin (40):

$\frac{K a_{m}}{K a_{w t}}=\frac{R_{m}}{R_{w t}} \times \frac{D_{w t}}{D_{m}} ;$ where $R n=\frac{D_{n}}{T_{n}}$

represents the molar ratio of dimer to tetramer for any given spectrin (n). Application of this equation to the self-association isotherms at different concentrations shown in Fig. 6 indicated that the overall observed $K a$ for spectrin self-association in the heterozygous parents is only $\sim 0.2 \pm 0.1$ ( $\pm 1 \mathrm{SD}$ ) of the normal association constant. Stated differently, the $K a$ for selfassociation of spectrin Buffalo is at least five times weaker than normal; given that most tetramer formation in the parents can be attributed to the wild-type protein, the actual $K a$ for spectrin Buffalo self-association is probably much weaker and similar to that for other spectrin mutations that cause severe clinical phenotypes $(21,43)$. In general, the degree of impairment of spectrin self-association parallels the clinical severity of the disorder in patients with $\operatorname{HE}$ or $\operatorname{HPP}(5,44)$.

\section{Molecular genetic analyses}

Nucleotide sequencing. Mutations frequently associated with the variant T $\alpha$-I 74-kD peptide have been identified in regions of the $\alpha \mathrm{I}-$ and $\beta I$-spectrin genes encoding the spectrin selfassociation site, i.e., in exon 2 of the $\alpha \mathrm{I}$-spectrin gene and in exons 30 and 31 of the $\beta I$-spectrin gene $(17,31,45,46)$. Genomic DNA corresponding to exon 2 of the $\alpha \mathrm{I}$-spectrin gene

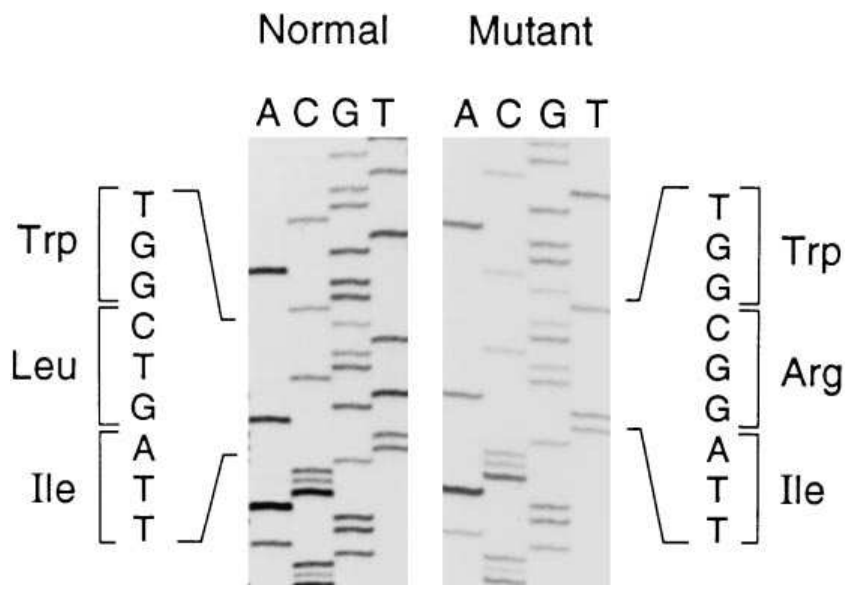

Figure 7. Nucleotide sequence of PCR-amplified genomic DNA from the mother of the proband (I-1). Genomic DNA was amplified by PCR using primers corresponding to exon 30 of the $\beta I$-spectrin gene (primers A + B in Table III). The PCR products were subcloned and individual clones were sequenced. In approximately half of the subclones, a point mutation was detected that changes a leucine (CㅌG) to arginine (CECT) at codon 2025 of the $\beta \mathrm{I}$-spectrin gene.
Table IV. Evolutionary Conservation of Leucine in Position 46 of Repeat 17 of the Proposed Triple Helical Repeat Model of $\beta$ Spectrin

\begin{tabular}{lclc}
\hline Sequence* & Species and isoform & Source of cDNA clone & Reference \\
\hline AWLIAQE & Human $\beta \mathrm{I}$ & Fetal liver & 46,54 \\
AWRIAQE & Human $\beta \mathrm{I}$ & Spectrin Buffalo & - \\
AWLLGQE & Human $\beta \mathrm{II}$ & Brain stem & 55 \\
AWLLGQE & Canine $\beta \mathrm{II}$ & Trachea & 56 \\
AWLIAQE & Murine $\beta \mathrm{I}$ & Reticulocyte & 57 \\
AWLLGQE & Murine $\beta \mathrm{II}$ & Brain & 58,59 \\
AWLIAQE & Drosophila & Head & 60 \\
& & & \\
\hline
\end{tabular}

*The conserved leucine appears in bold print.

and exons 30, 31, and 32 of the $\beta I$-spectrin gene were amplified by PCR using genomic DNA and oligonucleotide primers A + $\mathrm{B}, \mathrm{C}+\mathrm{D}$, and E $+\mathrm{F}$, respectively (Table III). Sequence analysis of subcloned, amplified genomic DNA fragments corresponding to exon 30 of the $\beta I$-spectrin gene, derived from individuals I-1 (mother) and II-4 (proband), revealed a single base substitution (CTG to CGG) that changes a leucine to an arginine at position 2025 of the $\beta$ I-spectrin chain (Fig. 7 B). This mutation occurs at position 46 of repeat 17 within helix 1 of the proposed triple helical conformational model of spectrin repeats $(15,41,46)$, corresponding to position A18 of the crystallographic structure of the spectrin repeat (16). Most mutations of the $80-\mathrm{kD}$ T $\alpha-\mathrm{I}$ domain of spectrin occur in helix three of the proposed model and are often at or adjacent to highly conserved residues of the homologous 106-amino acid repeats of spectrin $(17-19,47)$. The importance of leucine in this position of repeat 17 is highlighted by its evolutionary conservation in all $\beta$ spectrins from Drosophila to humans (Table IV).

To ensure that other HE/HPP mutations frequently associated with the variant T $\alpha-\mathrm{I} 74-\mathrm{kD}$ peptide were not present, PCR-amplified genomic DNA from the proband corresponding to exon 2 of the $\alpha \mathrm{I}$-spectrin gene and exons 30 and 31 of the $\beta I$-spectrin gene was examined $(31,45,46)$. The nucleotide sequence of all three exons was normal (data not shown).

PCR-based mutation detection. The authenticity of the spectrin Buffalo mutation was confirmed by restriction enzyme digestion of amplified genomic DNA. The mutation creates a novel AciI restriction enzyme site, CCGC, allowing for rapid, PCR-based detection of the mutation in the genomic DNA of each family member. Oligonucleotide primers $\mathrm{G}+\mathrm{H}$ (Table III) were synthesized corresponding to the sequence of $\beta$-spectrin gene flanking the region of the mutation; these primers amplify a fragment of $220 \mathrm{bp}$. Amplified genomic DNA fragments of normal individuals were digested with AciI into fragments of 158 and 62 bp (Fig. 8 A). AciI digestion of PCRamplified DNA from the parents and children II-2 and II-4 (Fig. 8 B) yielded fragments of $158+129+62+29$ (I-1 and I-2) or $129+62+29$ bp (II-2 and II-4) indicating that the mother and father are heterozygous for the spectrin Buffalo mutation and the two children are homozygous for the mutation. Material was not available from abortuses II-1 or II-3.

\section{Molecular modeling}

While the precise three-dimensional structure of the self-association domain is not known, dynamic molecular modeling coupled with energy minimization yields models of this struc- 

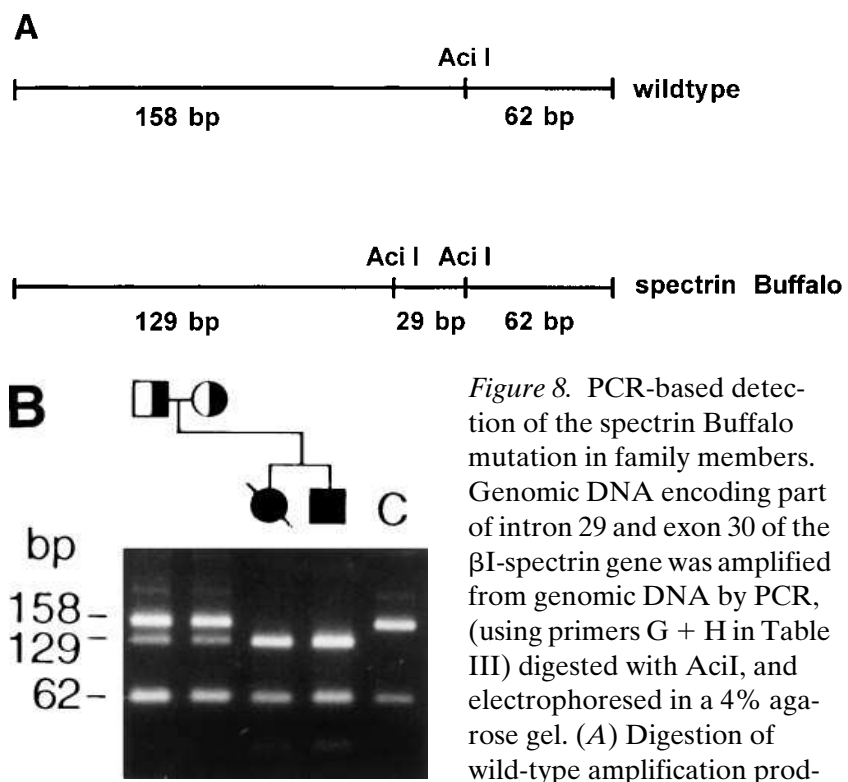

Figure 8. PCR-based detection of the spectrin Buffalo mutation in family members. Genomic DNA encoding part of intron 29 and exon 30 of the $\beta I$-spectrin gene was amplified from genomic DNA by PCR, (using primers $\mathrm{G}+\mathrm{H}$ in Table III) digested with AciI, and electrophoresed in a $4 \%$ agarose gel. $(A)$ Digestion of wild-type amplification products with AciI yields frag-

ments of 158 and $62 \mathrm{bp}$. Digestion of mutant spectrin Buffalo products yields fragments of 129,62 , and $29 \mathrm{bp}$. (B) AciI digestion of the parents amplified DNA yielded fragments of 158, 129, 62, and $29 \mathrm{bp}$ indicating that the mother and father possess both the wild-type and mutant alleles, i.e., are heterozygous for the spectrin Buffalo mutation. The 29-bp fragment is not seen on this gel. AciI digestion of amplified DNA from the children II-2 and II-4 yielded fragments of 129, 62 , and $29 \mathrm{bp}$ indicating that the children are homozygous for the mutation. Digestion of control $(C)$ amplification products yielded fragments of 158 and $62 \mathrm{bp}$.

ture and of other spectrin repeats that appear valid by most criteria, and which accurately predict that consequences of all mutations in this domain lead to failure of self-association (Stabach, P.R., C.D. Cianci, S.B. Glantz, Z. Zhang, and J.S. Morrow, manuscript submitted for publication; and Zhang, Z., S.A. Weed, and J.S. Morrow, manuscript in preparation). Specifically, alignment of the sequence of the repeat of Drosophila $\alpha$ spectrin with the sequences in $\alpha \mathrm{I}$ and $\beta \mathrm{I}$ spectrin that are involved with self-association identifies 73 substitutions, including 2 prolines present in the human sequence but not in the Drosophila sequence. While proline residues have classically been considered helix breaking residues, the dynamic modeling studies suggest that the structure of the wild-type human spectrin self-association domain is nearly identical to that of the Drosophila structure, despite the presence of prolines in helixes 1 and 2 (or A and B) which distort these helices only slightly in the minimal energy model, and the fact that $>69 \%$ of the repeat unit has been replaced with substitute residues compared with the Drosophila sequence (Fig. 9). However, the single mutation in spectrin Buffalo, with replacement of the hydrophobic leucine by arginine, is predicted to markedly destabilize the self-association domain by disrupting the hydrophobic interactions that tether helices $\mathrm{A}$ and $\mathrm{B}$. The predicted result is a splaying of these helices, a repositioning of the mutant arginine toward the solvent, a loss of the cleft between helices A and B that is necessary for the binding of $\alpha \mathrm{I}$ spectrin, and a loss of binding energy for the $\mathrm{NH}_{2}$-terminal $\alpha \mathrm{I}$ self-association domain. It is likely that this conformational change accounts for its loss of binding affinity as well as the increased proteolytic susceptibility of this region.

\section{Pathologic and immunohistochemical examination of skeletal muscle}

The region of $\beta I$ spectrin that participates in spectrin self-association (the location of the spectrin Buffalo mutation) is common to both the erythrocyte $\beta$-spectrin isoform $(\beta I \Sigma 1)$ and the $\beta I \Sigma 2$ isoform of spectrin expressed in muscle. $\beta I \Sigma 2$ spectrin is created by tissue-specific splicing (in muscle and brain) of $\beta$-spectrin pre-mRNA resulting in replacement of part of the last exon of $\beta I \Sigma 1$ (erythrocyte) spectrin with four additional exons (23). At the protein level, $\beta \mathrm{I} \Sigma 2$ replaces the $22 \mathrm{COOH}-$ terminal amino acids of $\beta I \Sigma 1$ spectrin with 213 novel amino acids. In mammalian skeletal muscle, $\beta \mathrm{I} \Sigma 2$ spectrin colocalizes with dystrophin in distinct subsarcolemmal domains (48). $\beta I \Sigma 2$ spectrin has been shown to self-associate both in vitro and in vivo with $\alpha$ II spectrin ( $\alpha$ fodrin, nonerythroid $\alpha$ spectrin) (12, $20,49,50)$. Although the impact of mutations in the region of the spectrin self-association site on the erythrocyte membrane have been well described in cases of hemolytic anemia, less is known about the phenotype of mutations of the $\beta I$-spectrin self-association domain in nonerythroid tissues. Only one mutation has been examined, that of spectrin Providence S2019P (10), which yields no phenotype in skeletal muscle (35). Therefore, it was important to determine if the spectrin Buffalo mutation led to any abnormalities of muscle in an individual homozygous for the mutation.

Sections of psoas muscle from a normal age-matched control (Fig. 10, $a-c$ ) and spectrin Buffalo kindred individual II-2 (Fig. 10, $d-f$ ) were studied by hematoxylin and eosin staining and immunohistochemical staining using an anti- $\beta \mathrm{I} \Sigma 2$ antibody. Three independent pathologic observations of hematoxylin and eosin-stained muscle sections from individual II-2 indicated normal architecture with no evidence of myopathy or other abnormality (Fig. 10, $a$ and $d$ ). Immunocytochemical staining of muscle with an anti- $\beta \mathrm{I} \Sigma 2$ antibody was performed. The utility of this antibody for staining paraffin-embedded tissue was determined by study of skeletal muscle from an agematched control subject (Fig. $10 b$ ) in which there was specific labeling of the sarcolemma. In individual II-2, $\beta$ I $\Sigma 2$ was also specifically localized to the sarcolemma in a distribution similar to that of normal muscle (Fig. $10 e$ ). The specificity of the anti- $\beta I \Sigma 2$ antibody in these tissues was confirmed by the lack of specific immunoreactivity when the samples were stained with a nonspecific rabbit $\operatorname{IgG}$ (Fig. 10, $c$ and $f$ ).

\section{Discussion}

Identification of the etiology of hemolytic anemia in a hydropic fetus or neonate as being due to an intrinsic defect of the erythrocyte may be difficult, requiring a number of specialized diagnostic tests (1). The most common type of intrinsic erythrocyte disorder associated with hydrops fetalis, homozygous $\alpha^{\circ}$-thalassemia, is also the easiest to diagnose by hemoglobin electrophoresis or specific DNA diagnostic testing. When an inherited deficiency of an erythrocyte enzyme is suspected, specific enzyme level determinations, performed only in specialized laboratories, are indicated. Enzyme deficiencies associated with hydrops fetalis have included that of glucose 6-phosphate dehydrogenase, pyruvate kinase, and glucosephosphate isomerase. This report extends the spectrum of 

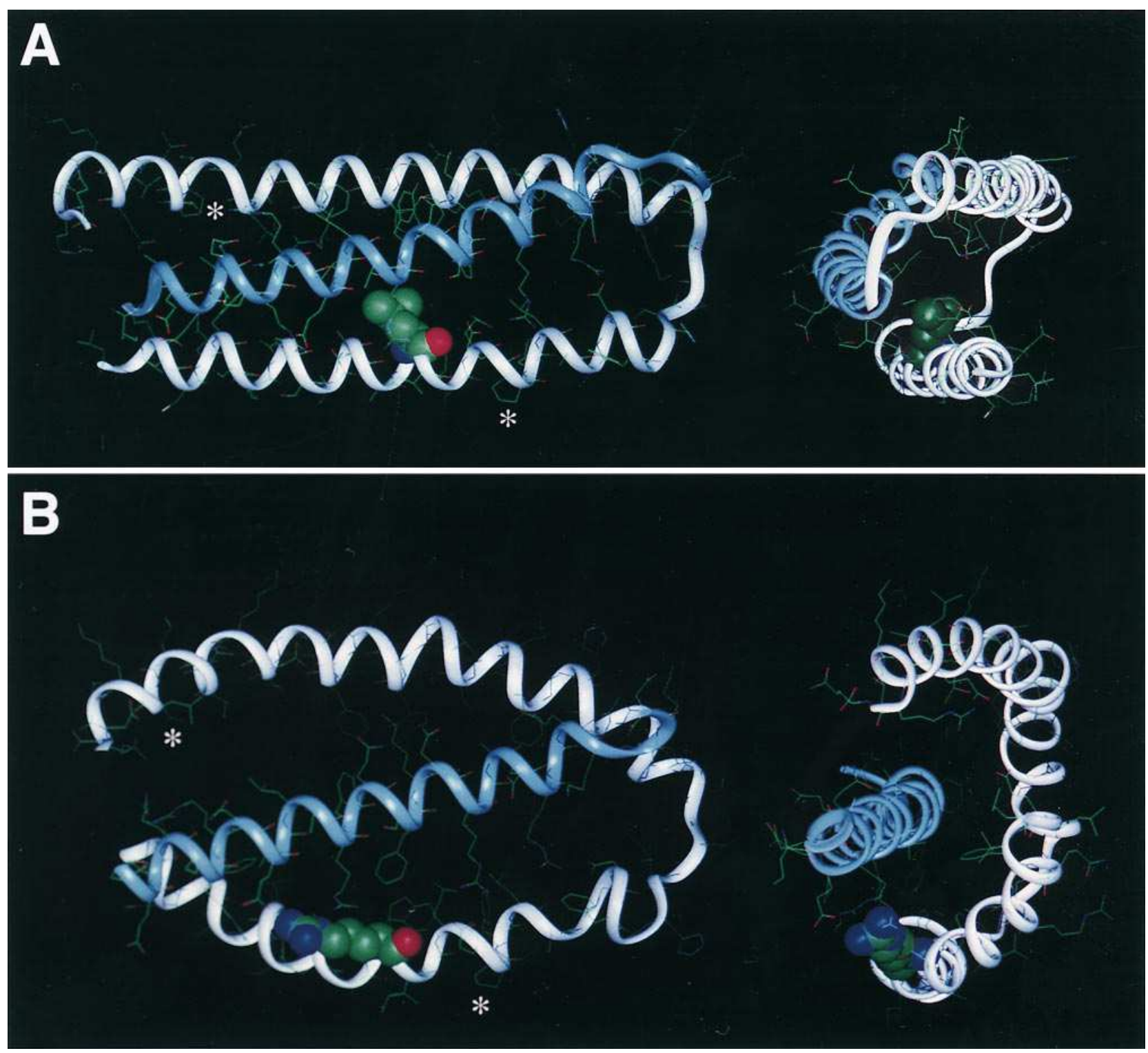

Figure 9. Dynamic molecular modeling of the structural effects of the spectrin Buffalo mutation. Dynamic molecular modeling suggests that the spectrin Buffalo mutation markedly disrupts the conformation of the self-association domain. Using the coordinates of the 14th repeat of Drosophila $\alpha$ spectrin as a starting point, the sequences of the self-association domain of $\beta \mathrm{I}$ spectrin (white, helices $\mathrm{A}$ and $\mathrm{B}$ ) and of $\alpha \mathrm{I}$ spectrin (blue, helix C) were aligned with the Drosophila sequence by homology, and the resultant structure was then modeled by dynamic and energy minimization techniques. Both lateral (left) and end-on (right) views of the modeled self-association complex are shown. The position of the mutated residue within the putative $A$ helix is shown as a space-filling representation. In this representation, the remainder of $\beta$ spectrin would lie to the left, while the remainder of $\alpha$ spectrin would lie to the right. $(A)$ Modeled structure of the normal self-association complex. Despite a difference of 73 amino acid residues in the human sequence compared with the Drosophila sequence, the modeled structure closely conforms to the structure of the Drosophila repeat unit as derived from the crystal coordinates. This structure exists even with the presence of two proline residues in the wild-type protein $(*)$, which distort the helices slightly but do not disrupt the native type complex. $(B)$ The modeled structure of the self-association complex of spectrin Buffalo. Note that the presence of the mutated arginine is predicted to disrupt the juxtapositioning of helix A with respect to helix B, with a loss of the normal binding cleft for $\alpha$ spectrin. Without this stabilization of binding, the distorting effect of the prolines is also more apparent.

erythrocyte membrane disorders associated with the hydrops fetalis syndrome. Previously, only two kindreds with erythrocyte membrane disorders associated with hydrops fetalis had been reported $(10,11)$. The unifying theme in all three kindreds is that one or both of the parents were initially thought to be hematologically normal, but additional specialized diagnostic testing of parental erythrocytes implicated the mem- brane skeleton in the pathogenesis of the hydrops fetalis. This observation emphasizes the importance of carefully analyzing the parent's erythrocytes when investigating a case of hydrops fetalis thought to be due to a hematologic cause.

Besides spectrin Buffalo, three other amino acid substitutions have been described in this region of $\beta I$ spectrin in the homozygous state: spectrin Providence (S2019P) (10), spectrin 


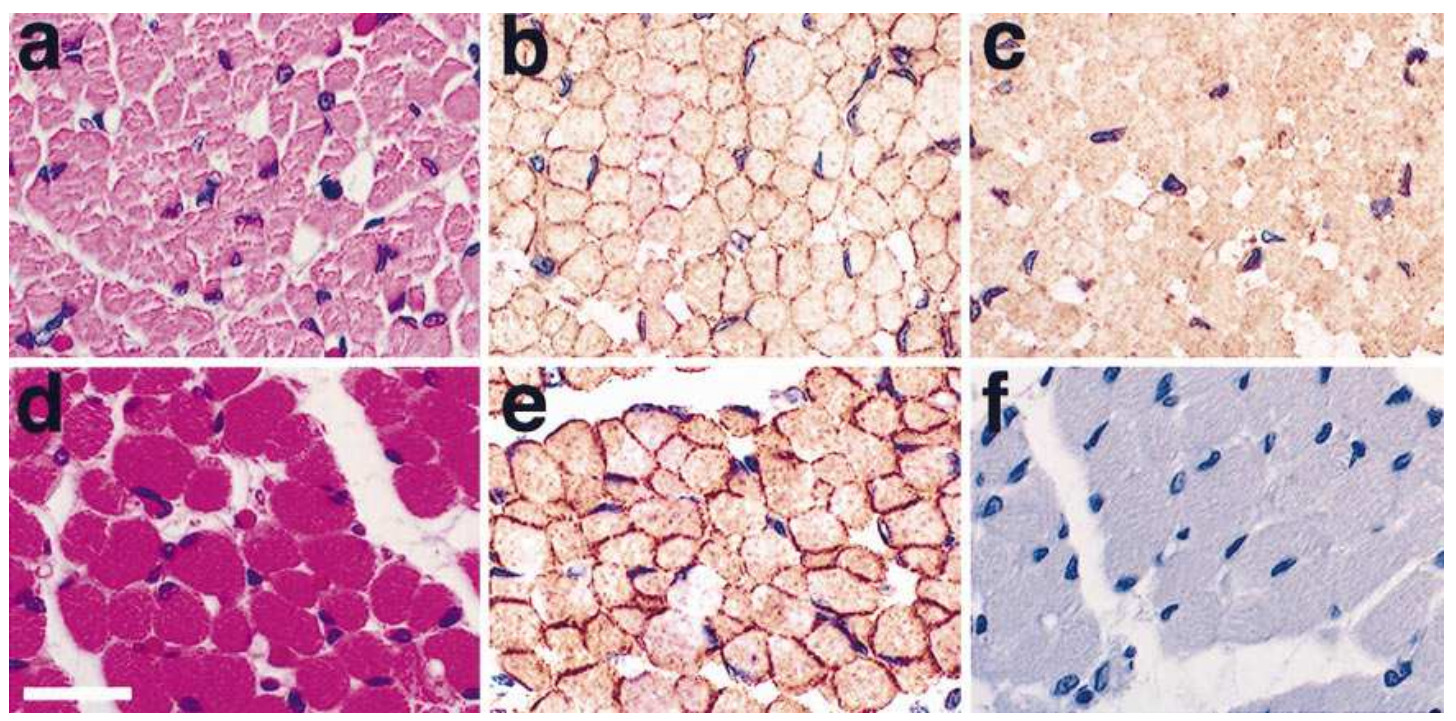

Figure 10. Pathologic and immunohistochemical examination of skeletal muscle from individual II-2. Formalin-fixed paraffin-embedded skeletal muscle sections from a normal, age-matched control $(a-c)$ and from individual II-2 of the spectrin Buffalo kindred $(d-f)$ were studied. $a$ and $d$ were stained with hematoxylin and eosin $(\operatorname{bar}, 50 \mu \mathrm{m}), b$ and $e$ were stained with an anti- $\beta I \Sigma 2$ antibody, and $c$ and $f$ were stained with a nonspecific rabbit IgG. Differences in color are due to variation in background staining and photographic technique. The morphologic appearance and distribution of $\beta I \Sigma 2$ from individual II-2 who is homozygous for the spectrin Buffalo mutation is not significantly different from that of normal muscle.

Cagliari (A2018G) (8), and spectrin Kayes (A2053P) (9). All three mutants exhibit similar findings. Heterozygous individuals are clinically asymptomatic with peripheral blood smears that exhibit very mild to moderate elliptocytosis; their erythrocytes have normal spectrin content and a mild to moderate defect in spectrin self-association. Homozygous individuals who survive the neonatal period exhibit severe hemolysis and anemia necessitating frequent blood transfusions until splenectomy is performed in early childhood. Erythrocytes from homozygous individuals exhibit a severe defect in spectrin selfassociation. Compared with these three kindreds, the spectrin Buffalo kindred is unique in several aspects. First, homozygosity for the spectrin Buffalo mutation was fatal in one individual, while the other remains transfusion-dependent with a severe, ongoing hemolytic anemia. Second, this kindred provides important information on the role of $\beta I S p$ in muscle by giving us the opportunity to examine the effect of homozygosity for a $\beta I S p$ mutation on muscle in a living homozygote (by physical examination), as well as in the deceased homozygote (by pathologic and immunohistochemical analyses). Finally, the three previously reported mutations were all missense mutations known to disrupt $\alpha$-helices, proline or glycine, whereas the spectrin Buffalo mutation is a charge shift mutation in a highly conserved residue.

Determination of the crystal structure of a typical spectrin repeat (16), in conjunction with dynamic molecular modeling, has enabled us to analyze the effects of the spectrin Buffalo mutation on spectrin structure. The positively charged, hydrophilic arginine replaces an uncharged, hydrophobic leucine at a location in the interior of the triple helix where hydrophobic interactions occur, i.e., ridge-to-ridge packing, between helix 1 (helix A) and helix 2 (helix B) of the $\beta I$-spectrin chain. As a result of this amino acid replacement, there is profound alteration of the conformation of the $\alpha \mathrm{I}$-spectrin binding site. Thus, this amino acid replacement disrupts the intrachain interac- tions important in maintaining the conformation of the region of $\beta \mathrm{I}$ spectrin that is critical for spectrin self-association. This change also disrupts the interchain interactions between $\alpha \mathrm{I}$ and $\beta \mathrm{I}$ spectrin that are important in the formation of the terminal hybrid $(\alpha$ and $\beta$ ) triple helical repeat that constitutes the spectrin self-association site. As a result, in the homozygous state, this mutation appears to produce erythrocytes with severely unstable membranes.

Patients with inherited hemolytic anemias associated with myopathic or neurologic system symptoms have been described (4, 51-53). However, precise molecular defects have not been identified in these patients. Of the three reported kindreds of individuals homozygous for $\beta I$-spectrin self-association site mutations (8-10), only a single study of muscle architecture has been reported (35). In that study, no muscle phenotype was identified in two individuals homozygous for the spectrin Providence mutation. $\beta I \Sigma 2$ spectrin exists in muscle in two populations: one associated with $\alpha \mathrm{II}$ spectrin at the sarcolemma, the other as unpaired homodimers localized to the sarcolemma or in the myoplasm $(12,35,48)$. Thus, theoretically, the spectrin Buffalo mutation should disrupt the self-association of $\alpha \mathrm{II} / \beta \mathrm{I} \Sigma 2$ dimers into tetramers in muscle. The finding of no apparent disruption of muscle architecture either on pathologic examination or on immunohistochemical analysis raises a number of considerations.

It is possible that $\alpha \mathrm{II} / \beta \mathrm{I} \Sigma 2$ tetramers are formed in such a stable manner in muscle that a single point mutation of $\beta$ spectrin does not lead to a detectable phenotype. However, sedimentation analysis of muscle cells transfected with spectrin Providence suggests that such stable tetramers are, in fact, not formed (35). The role of other spectrin isoforms in muscle and whether or not there is plasticity or redundancy among members of the spectrin family of proteins in muscle are unknown. It is important to note that $\beta I$-spectrin mutations of the selfassociation site in repeat 17 that disrupt the reading frame 
(e.g., insertions, deletion, splicing mutations) of both the erythroid $(\beta I \Sigma 1)$ and the nonerythroid $(\beta I \Sigma 2)$ transcript have not been identified yet in the homozygous state. It has been hypothesized that homozygosity for this type of mutation would be lethal, as they would delete the $\mathrm{COOH}$-terminal regions of both the $\beta I \Sigma 1$ and $\beta I \Sigma 2$ isoforms of spectrin.

Alternatively, perhaps spectrin self-association does not play the critical role in muscle that it does in the erythrocyte. In muscle, dystrophin and members of the dystrophin-glycoprotein complex provide structural support for the sarcolemma during the stress of muscle contraction and relaxation. The $\beta I \Sigma 2$ isoform has been colocalized with dystrophin at the sarcolemma (48), but its precise role is undefined. $\beta I \Sigma 2$ spectrin could be redundant in the muscle cell or perhaps plays another, as yet undiscovered, function in muscle. The description of $\beta$-spectrin isoform homodimers in muscle that do not apparently use the self-association site (49) provides further evidence that in some nonerythroid cells $\beta$ spectrin may be organized differently than in RBCs and may have other functions unrelated to self-association. If $\beta I \Sigma 2$ spectrin does play a critical role in skeletal muscle, the homozygous, transfusion-dependent, living child II-4, like many individuals with abnormalities of dystrophin, may develop myopathic symptoms later in life.

\section{Acknowledgments}

We thank Dr. John Fisher for supplying pathologic materials. The contributions of Yale's Critical Technologies Laboratory to the procurement of normal human skeletal muscle and the immunohistochemical studies are gratefully acknowledged.

This work was supported in part by grants from the National Institutes of Health, the March of Dimes Birth Defects Foundation, and the American Heart Association, Connecticut Affiliate.

\section{References}

1. Arcasoy, M.O., and P.G. Gallagher. 1995. Hematologic disorders and nonimmune hydrops fetalis. Semin. Perinatol. 19:502-515.

2. Agre, P., E.P. Orringer, and V. Bennett. 1982. Deficient red-cell spectrin in severe, recessively inherited spherocytosis. N. Engl. J. Med. 306:1155-1161.

3. Agre, P., J.F. Casella, W.H. Zinkham, C. McMillan, and V. Bennett. 1985. Partial deficiency of erythrocyte spectrin in hereditary spherocytosis. $\mathrm{Na}$ ture (Lond.). 314:380-383.

4. Coetzer, T.L., J. Lawler, S.C. Liu, J.T. Prchal, R.J. Gualtieri, M.C. Brain, J.V. Dacie, and J. Palek. 1988. Partial ankyrin and spectrin deficiency in severe, atypical hereditary spherocytosis. N. Engl. J. Med. 318:230-234.

5. Coetzer, T., J. Palek, J. Lawler, S.C. Liu, P. Jarolim, M. Lahav, J.T. Prchal, W. Wang, B.P. Alter, G. Schewitz, et al. 1990. Structural and functional heterogeneity of $\alpha$-spectrin mutations involving the spectrin heterodimer self-association site: relationships to hematologic expression of homozygous hereditary elliptocytosis and hereditary pyropoikilocytosis. Blood. 75:2235-2244.

6. Dhermy, D., M. Garbarz, M.C. Lecomte, C. Feo, O. Bournier, I. Chaveroche, H. Gautero, C. Galand, and P. Boivin. 1986. Hereditary elliptocytosis: clinical, morphological and biochemical studies of 38 cases. Nouv. Rev. Fr. Hematol. 28:129-140.

7. Gallagher, P.G., W.T. Tse, T. Coetzer, M.C. Lecomte, M. Garbarz, H.S. Zarkowsky, A. Baruchel, S.K. Ballas, D. Dhermy, J. Palek, and B. Forget. 1992. A common type of the spectrin $\alpha \mathrm{I} 46-50-\mathrm{kD}$ peptide abnormality in hereditary elliptocytosis and pyropoikilocytosis is associated with a mutation distant from the proteolytic cleavage site. Evidence for the functional importance of the triple helical model of spectrin. J. Clin. Invest. 89:892-898.

8. Sahr, K.E., T.L. Coetzer, L.S. Moy, L.H. Derick, A.H. Chishti, P. Jarolim, F. Lorenzo, E. Miraglia del Giudice, A. Iolascon, R. Gallanello, et al. 1993. An Ala $\rightarrow$ Gly substitution in helix 1 of $\beta$-spectrin repeat 17 that severely disrupts the structure and self-association of the erythrocyte spectrin heterodimer. J. Biol. Chem. 268:22656-22662.

9. Tse, W.T., M.C. Lecomte, F.F. Costa, M. Garbarz, C. Feo, P. Boivin, D. Dhermy, and B.G. Forget. 1990. Point mutation in the $\beta$-spectrin gene associated with $\alpha \mathrm{I} / 74$ hereditary elliptocytosis. Implications for the mechanism of spectrin dimer self-association. J. Clin. Invest. 86:909-916.
10. Gallagher, P.G., S.A. Weed, W.T. Tse, L. Benoit, J.S. Morrow, S.L. Marchesi, N. Mohandas, and B.G. Forget. 1995. Recurrent fatal hydrops fetalis associated with a nucleotide substitution in the erythrocyte $\beta$-spectrin gene. $J$. Clin. Invest. 95:1174-1182.

11. Whitfield, C.F., J.B. Follweiler, L. Lopresti-Morrow, and B.A. Miller. 1991. Deficiency of $\alpha$-spectrin synthesis in burst-forming units-erythroid in lethal hereditary spherocytosis. Blood. 78:3043-3051.

12. Malchiodi-Albedi, F., M. Ceccarini, J.C. Winkelmann, J.S. Morrow, and T.C. Petrucci. 1993. The $270 \mathrm{kDa}$ splice variant of erythrocyte $\beta$-spectrin $(\beta I \Sigma 2)$ segregates in vivo and in vitro to specific domains of cerebellar neurons. J. Cell Sci. 106:67-78.

13. Morrow, J.S., D.L. Rimm, S.P. Kennedy, C.D. Cianci, J.H. Sinard, and S.A. Weed. 1997. Of membrane stability and mosaics: the spectrin cytoskeleton. In Handbook of Physiology. J. Hoffman and J. Jamieson, editors. Oxford University Press, London. In press.

14. Winkelmann, J.C., and B.G. Forget. 1993. Erythroid and nonerythroid spectrins. Blood. 81:3173-3185.

15. Speicher, D.W., and V.T. Marchesi. 1984. Erythrocyte spectrin is comprised of many homologous triple helical segments. Nature (Lond.). 311:177180.

16. Yan, Y., E. Winograd, A. Viel, T. Cronin, S.C. Harrison, and D. Branton. 1993. Crystal structure of the repetitive segments of spectrin. Science (Wash. DC). 262:2027-2030.

17. Delaunay, J., and D. Dhermy. 1993. Mutations involving the spectrin heterodimer contact site: clinical expression and alterations in specific function. Semin. Hematol. 30:21-33.

18. Benz, E.J., Jr. 1994. The erythrocyte membrane and cytoskeleton: structure, function and disorders. In The Molecular Basis of Blood Diseases. 2nd ed. G. Stamatoyannopoulos, A.W. Nienhuis, P.W. Majerus, and H. Barmus, editors. W.B. Saunders Co., Philadelphia. 257-292.

19. Lux, S.E., and J. Palek. 1995. Disorders of the red cell membrane. In Blood: Principles and Practice of Hematology. R.I. Handin, S.E. Lux, and T.P. Stossel, editors. J.B. Lippincott, Philadelphia. 1701-1816.

20. Kennedy, S.P., S.A. Weed, B.G. Forget, and J.S. Morrow. 1994. A partial structural repeat forms the heterodimer self-association site of all $\beta$-spectrins. J. Biol. Chem. 269:11400-11408.

21. Knowles, W.J., J.S. Morrow, D.W. Speicher, H.S. Zarkowsky, N. Mohandas, W.C. Mentzer, S.B. Shohet, and V.T. Marchesi. 1983. Molecular and functional changes in spectrin from patients with hereditary pyropoikilocytosis. J. Clin. Invest. 71:1867-1877.

22. Kotula, L., T.M. DeSilva, D.W. Speicher, and P.J. Curtis. 1993. Functional characterization of recombinant human red cell $\alpha$-spectrin polypeptides containing the tetramer binding site. J. Biol. Chem. 268:14788-14793.

23. Winkelmann, J.C., F.F. Costa, B.L. Linzie, and B.G. Forget. 1990. $\beta$ spectrin in human skeletal muscle. Tissue-specific differential processing of $3^{\prime} \beta$ spectrin pre-mRNA generates a $\beta$-spectrin isoform with a unique carboxyl terminus. J. Biol. Chem. 265:20449-20454.

24. Johnson, R.M. 1975. The kinetics of resealing of washed erythrocyte ghosts. J. Membr. Biol. 22:231-253.

25. Mohandas, N., M.R. Clark, B.P. Health, M. Rossi, L.C. Wolfe, S.E. Lux, and S.B. Shohet. 1982. A technique to detect reduced mechanical stability of red cell membranes: relevance to elliptocytic disorders. Blood. 59:768-774.

26. Fairbanks, G., T.L. Steck, and D.F. Wallach. 1971. Electrophoretic analysis of the major polypeptides of the human erythrocyte membrane. Biochemistry. 10:2606-2617.

27. Marchesi, S.L., W.J. Knowles, J.S. Morrow, M. Bologna, and V.T. Marchesi. 1986. Abnormal spectrin in hereditary elliptocytosis. Blood. 67:141151.

28. Ungewickell, E., and W. Gratzer. 1978. Self-association of human spectrin. A thermodynamic and kinetic study. Eur. J. Biochem. 88:379-385.

29. Speicher, D.W., J.S. Morrow, W.J. Knowles, and V.T. Marchesi. 1980. Identification of proteolytically resistant domains of human erythrocyte spectrin. Proc. Natl. Acad. Sci. USA. 77:5673-5677.

30. Marchesi, S.L., J.T. Letsinger, D.W. Speicher, V.T. Marchesi, P. Agre, B. Hyun, and G. Gulati. 1987. Mutant forms of spectrin $\alpha$-subunits in hereditary elliptocytosis. J. Clin. Invest. 80:191-198.

31. Sahr, K.E., T. Tobe, A. Scarpa, K. Laughinghouse, S.L. Marchesi, P. Agre, A.J. Linnenbach, V.T. Marchesi, and B.G. Forget. 1989. Sequence and exon-intron organization of the DNA encoding the $\alpha$ I domain of human spectrin. Application to the study of mutations causing hereditary elliptocytosis. $J$. Clin. Invest. 84:1243-1252.

32. Kiyabu, M.T., D. Shibata, N. Arnheim, W.J. Martin, and P.L. Fitzgibbons. 1989. Detection of human papilloma virus in formalin-fixed, invasive squamous carcinomas using the polymerase chain reaction. Am. J. Surg. Pathol. 13:221-224.

33. Devereux, J., P. Haeberli, and O. Smithies. 1984. A comprehensive set of sequence analysis programs for the VAX. Nucleic Acids Res. 12:387-395.

34. Verlet, L. 1967. Computer experiments on classical fluid. I. Thermodynamical properties of Lennard-Jones molecules. Physical Reviews. 159:98-103.

35. Weed, S.A., P.R. Stabach, C.E. Oyer, P.G. Gallagher, and J.S. Morrow. 1996. The lethal hemolytic mutation in $\beta I \Sigma 2$ spectrin Providence yields a null phenotype in neonatal skeletal muscle. Lab. Invest. 74:1117-1129. 
36. Younes, M., A.S. Harris, and J.S. Morrow. 1989. Fodrin as a differentiation marker. Redistributions in colonic neoplasia. Am. J. Pathol. 135:11971212.

37. Norton, A.J., S. Jordan, and P. Yeomans. 1994. Brief, high-temperature heat denaturation (pressure cooking): a simple and effective method of antigen retrieval for routinely processed tissues. J. Pathol. 173:371-379.

38. Lombardo, C.R., S.A. Weed, S.P. Kennedy, B.G. Forget, and J.S. Morrow. 1994. $\beta \mathrm{II}$-spectrin (fodrin) and $\beta \mathrm{I} \Sigma 2$-spectrin (muscle) contain $\mathrm{NH}_{2}$ - and $\mathrm{COOH}$-terminal membrane association domains (MAD1 and MAD2). J. Biol. Chem. 269:29212-29219.

39. Iarocci, T.A., G.M. Wagner, N. Mohandas, P.A. Lane, and W.C. Mentzer. 1988. Hereditary poikilocytic anemia associated with the co-inheritance of two $\alpha$-spectrin abnormalities. Blood. 71:1390-1396.

40. Morrow, J.S., D.W. Speicher, W.J. Knowles, C.J. Hsu, and V.T. Marchesi. 1980. Identification of functional domains of human erythrocyte spectrin. Proc. Natl. Acad. Sci. USA. 77:6592-6596.

41. Speicher, D.W., T.M. DeSilva, K.D. Speicher, J.A. Ursitti, P. Hembach, and L. Weglarz. 1993. Location of the human red cell spectrin tetramer binding site and detection of a related "closed" hairpin loop dimer using proteolytic footprinting. J. Biol. Chem. 268:4227-4235.

42. Speicher, D.W., J.S. Morrow, W.J. Knowles, and V.T. Marchesi. 1982. A structural model of human erythrocyte spectrin. Alignment of chemical and functional domains. J. Biol. Chem. 257:9093-9101.

43. Gallagher, P.G., M.C. Lecomte, C. Galand, Y.P. Wang, W.T. Tse, and B.G. Forget. 1994. Location and PCR-based detection of three polymorphisms of the human erythrocyte $\beta$-spectrin gene (SPTB). Br. J. Haematol. 88:413-414.

44. Liu, S.C., J. Palek, and J.T. Prchal. 1982. Defective spectrin dimer-dimer association with hereditary elliptocytosis. Proc. Natl. Acad. Sci. USA. 79:20722076.

45. Amin, K.M., A.L. Scarpa, J.C. Winkelmann, P.J. Curtis, and B.G. Forget. 1993. The exon-intron organization of the human erythroid $\beta$-spectrin gene. Genomics. 18:118-125.

46. Winkelmann, J.C., J.G. Chang, W.T. Tse, A.L. Scarpa, V.T. Marchesi, and B.G. Forget. 1990. Full-length sequence of the cDNA for human erythroid $\beta$-spectrin. J. Biol. Chem. 265:11827-11832.

47. Dhermy, D. 1991. The spectrin super-family. Biol. Cell. 71:249-254

48. Porter, G.A., G.M. Dmytrenko, J.C. Winkelmann, and R.J. Bloch. 1992. Dystrophin colocalizes with $\beta$-spectrin in distinct subsarcolemmal domains in mammalian skeletal muscle. J. Cell Biol. 117:997-1005.
49. Weed, S.A. 1996. The spectrin cytoskeleton of muscle: isoform diversity and function. Ph.D. thesis. Yale University, New Haven, CT.

50. Clark, M.B., Y. Ma, M.L. Bloom, J.E. Barker, I.S. Zagon, W.E. Zimmer, and S.R. Goodman. 1994. Brain $\alpha$ erythroid spectrin: identification, compartmentalization, and $\beta$ spectrin associations. Brain Res. 663:223-236.

51. McCann, S.R., and H.S. Jacob. 1976. Spinal cord disease in hereditary spherocytosis: report of two cases with a hypothesized common mechanism for neurologic and red cell abnormalities. Blood. 48:259-263.

52. Moiseyev, V.S., E.A. Korovina, E.L. Polotskaya, I.S. Poliyanskaya, and V.V. Yazdovsky. 1987. Hypertrophic cardiomyopathy associated with hereditary spherocytosis in three generations of one family [letter]. Lancet. 2:853-854

53. Spencer, S.E., F.O. Walker, and S.A. Moore. 1987. Chorea-amyotrophy with chronic hemolytic anemia: a variant of chorea-amyotrophy with acanthocytosis. Neurology. 37:645-649.

54. Winkelmann, J.C., T.L. Leto, P.C. Watkins, R. Eddy, T.B. Shows, A.J. Linnenbach, K. E. Sahr, N. Kathuria, V. T. Marchesi, and B. G. Forget. 1988 Molecular cloning of the cDNA for human erythrocyte $\beta$-spectrin. Blood. 72: $328-334$.

55. Hu, R.J., M. Watanabe, and V. Bennett. 1992. Characterization of human brain cDNA encoding the general isoform of $\beta$-spectrin. J. Biol. Chem. 267:18715-18722.

56. Tan, S., V. Shankar, M.S. Gilmore, and G.P. Sachdev. 1993. Nucleotide sequence of a cDNA for canine $\beta$-spectrin reveals high evolutionary conservation. Biochim. Biophys. Acta. 1172:217-219.

57. Bloom, M.L., C.S. Birkenmeier, and J.E. Barker. 1993. Complete nucleotide sequence of the murine erythroid $\beta$-spectrin cDNA and tissue-specific expression in normal and jaundiced mice. Blood. 82:2906-2914.

58. Ma, Y., W.E. Zimmer, B.M. Riederer, M.L. Bloom, J.E. Barker, S.R. Goodman, and S.M. Goodman. 1993. The complete amino acid sequence for brain $\beta$ spectrin ( $\beta$ fodrin): relationship to globin sequences [published errata appear in Brain Res. Mol. Brain Res. 1993. 20:179 and 1994. 21:181]. Brain Res. Mol. Brain Res. 18:87-99.

59. Zimmer, W.E., Y.P. Ma, and S.R. Goodman. 1991. Identification of a mouse brain $\beta$-spectrin cDNA and distribution of its mRNA in adult tissues. Brain Res. Bull. 27:187-193.

60. Byers, T.J., E. Brandin, R.A. Lue, E. Winograd, and D. Branton. 1992 The complete sequence of Drosophila $\beta$-spectrin reveals supra-motifs comprising eight 106-residue segments. Proc. Natl. Acad. Sci. USA. 89:6187-6191. 